\title{
The impact of covid-19 on global insurance market
}

\author{
Ana Preda ${ }^{1, *}$, Mirela Popescu ${ }^{2}$, Imola Drigă ${ }^{3}$ \\ ${ }^{1}$ University of Petrosani, Universitatii Street, No.20, Petrosani, Romania
}

\begin{abstract}
The purpose of the paper is to present the changes occurred on global insurance markets during the current pandemic situation. The effects are largely felt through asset risks, weaker premium growth prospects, and also insurers' long-term investment. Developed markets, particularly life ones, are likely to shrink in real terms as a result of the economic slowdown. Higher mortality rates due to the coronavirus pandemic are affecting the bottom lines of many life insurers. The main trends in this sector in last years, is based on the most important aspects such as, written premiums, and benefits paid, types of the life insurance contracts and density and penetration degree of the life insurance sector.
\end{abstract}

\section{Introduction}

The insurance industry is generally well prepared for major loss events, including pandemics, but the financial impact will take time to assess and will be insurer and reinsurer specific. Covid-19 crisis mainly affected solvency and profitability of the insurance sector. At the beginning of the initial financial market shock, the global insurance sector has shown resilience - helped through monetary and fiscal support measures on financial markets in some regions. However, potential vulnerabilities remain, given uncertainties about duration and impact Covid-19 crisis. International reports show that in the first half of 2020, insurers' solvency rates have fell slightly, but overall the sector insurance remained resilient. Solvency rates have fallen in the first quarter of 2020 but somehow recovered in the second quarter.

An immediate implication of the pandemic for life insurance companies was the tragic human tribute affecting life insurance and annuity coverage. There has been a significant increase in premature deaths, and automatically increased mortality risk liabilities for many life insurance products. But it should be noted that the extent of the effects depends very much on the age profile of the insured and also on where they live.

It should also be noted that life insurers often provide protection against longevity risk through contingent life annuity products. Therefore, there may be a reduction in the expected longevity risk of annuities already cancelled from pandemic deaths. Life insurance companies have significant assets to cover their liabilities, changes in the financial markets can have various implications. For example, although equity markets have largely recovered from significant declines, future volatility and declining equity remain significant threats to solvency ratios.

*Corresponding author: ana_preda79@yahoo.com 
Low interest rates have repercussions for life insurance companies because they are particularly sensitive to long-term interest rates. The net effect on the balance sheets will depend on the duration of the asset compared to the duration of the liability. Life insurers usually have longer-term liabilities than assets available in the markets. Therefore, the net effect of a long-term reduction in interest rates on balance sheets is likely to be negative.

Insurers have made additional efforts to keep their customers well informed during the crisis by setting up dedicated websites and engaging in targeted information activities. Some companies have also made additional efforts to help protect customers from fraud, especially online fraud which has grown during the crisis.

Each insurance company is different in size and risk profile and is affected differently by COVID-19. The first duty of any company is to ensure that it can keep its promises to its customers. This means prudent management of its capital, especially in times of economic turmoil, so as not to jeopardize its ability to deliver on contractual promises to its customers now and in the future.

\section{Global Insurance Market Trends}

In 2020, the world faced an unexpected challenge as a new virus spread rapidly around the globe. Quick becoming a pandemic, COVID-19 has threatened people's health and affected people's lives and livelihoods as governments tried to limit the spread of the virus through preventative measures, such as quarantine and business closures. This unprecedented health crisis and government responses, it completely changed the normal activities of people and businesses, in turn affecting the business performance and damage experience of insurers.

Coronavirus blockages in 2020 call for universal learning and the widespread use of digital channels for day-to-day transactions. Customer behaviour is defined by two global factors when it comes to buying insurance: social media behaviour and shopping preferences. Clients trust online research and social media testimonials from friends about broker / agent advice, and you feel ready to make independent policy buying decisions. Although it is not surprising that more and many millennials use digital channels as part of everyday life, it is worth noting that previous generations began to use these modern methods of communication (Fig 1).

\begin{tabular}{|lcc|}
\hline & Millennials (born after 1980) & Gen X or older (born in 1980 or eartier) \\
\hline 2018 & $54 \%$ & $30 \%$ \\
\hline 2019 & $57 \%$ & $63 \%$ \\
\hline
\end{tabular}

Source: World Insurance Report 2020

Fig. 1. Customers frequently doing transactions online

Preliminary data and estimates available for the first quarters of 2020 would suggest that the evolution of underwritten premiums varied greatly depending on the type of insurance business. According to Worldwide Reports, gross written premiums decreased in the first half of 2020 in the life segment compared to the same period in 2019 (from EUR 447 billion in the first quarter of 2019 to EUR 396 billion in the first quarter of 2020), while they increased in the non-life segment (from EUR 272 billion in Q1 2019 to EUR 282 billion in Q1 2020). 


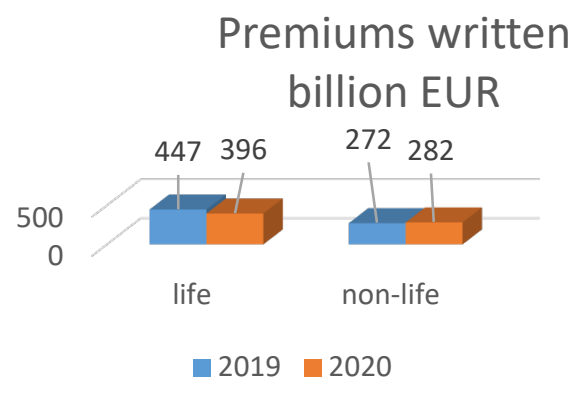

Fig. 2. Worldwide gross written premiums

One explanation for the decrease in gross written premiums in the life segment, is the increase of expiration rate or a decline in new business written. Difficulty meeting in person may have contributed to declining sales of a new life insurance policy. In some countries, it is a legal requirement for customers to take out insurance during physical meetings to allow for face-to-face identification, which limits the possibility of selling new contracts during COVID-19. Some countries have relaxed these types of temporary requirements in response to the health crisis.

We expect the COVID-19 crisis to have a severe negative impact on global life premiums, inflicting an average annual contraction of $1.5 \%$ in 2021. Aggregate advanced market life premium growth slowed to $1.3 \%$ in 2019 , still stronger than the annual average of the previous 10 years. US premium growth decelerated to $1.4 \%$ from $5.1 \%$ in 2018 , with an increase in ordinary life sales not fully offsetting a slowdown in annuities

In this context, Asian countries expect to recover faster, will continue to change the opportunity of the global insurance market to emerging Asia and especially China. China's share of global premiums will continue to grow rapidly to about $18 \%$ in 2030 , still only half of the US share. China remains on track to become the world's largest insurance market by the mid-2030s. By then, India, another emerging giant, will also be among the top 10 insurance markets.

\begin{tabular}{rlrrrrrr} 
& & \multicolumn{3}{c}{ Global market share } & \multicolumn{2}{c}{ Total premium volume (USD bn) } \\
\hline 1 & US & $\mathbf{1 9 8 0}$ & $\mathbf{2 0 1 9}$ & $\mathbf{2 0 3 0 F}$ & $\mathbf{1 9 8 0}$ & $\mathbf{2 0 1 9}$ & $\mathbf{2 0 3 0 \mathrm { F }}$ \\
\hline 2 & China & $\mathbf{4 6 \%}$ & $39 \%$ & $36 \%$ & 229 & 2460 & 3660 \\
\hline 3 & Japan & $0.0 \%$ & $10 \%$ & $18 \%$ & - & 617 & 1777 \\
\hline 4 & UK & $15 \%$ & $7.3 \%$ & $6.1 \%$ & 75 & 459 & 621 \\
\hline 5 & France & $6.9 \%$ & $5.8 \%$ & $4.0 \%$ & 35 & 366 & 404 \\
\hline 6 & Germany & $5.1 \%$ & $4.2 \%$ & $3.2 \%$ & 26 & 262 & 325 \\
\hline 7 & South Korea & $8.0 \%$ & $3.9 \%$ & $3.2 \%$ & 40 & 244 & 320 \\
\hline 8 & Italy & $0.3 \%$ & $2.8 \%$ & $2.5 \%$ & 2 & 175 & 258 \\
\hline 9 & Canada & $1.7 \%$ & $2.7 \%$ & $2.4 \%$ & 8 & 168 & 247 \\
\hline 10 & Taiwan & $2.6 \%$ & $2.1 \%$ & $2.0 \%$ & 13 & 133 & 205 \\
\hline 11 & India & $0.1 \%$ & $1.9 \%$ & $2.0 \%$ & 1 & 118 & 205 \\
\hline 12 & Netherlands & $0.4 \%$ & $1.7 \%$ & $2.3 \%$ & 2 & 106 & 234 \\
\hline 13 & Ireland & $2.1 \%$ & $1.3 \%$ & $1.1 \%$ & 10 & 84 & 110 \\
\hline 14 & Brazil & $0.2 \%$ & $1.2 \%$ & $1.1 \%$ & 1 & 75 & 114 \\
\hline 15 & Hong Kong & $0.4 \%$ & $1.2 \%$ & $0.9 \%$ & 2 & 74 & 91 \\
\hline Source: Swiss Re Institute & & $1.1 \%$ & $1.2 \%$ & - & 72 & 126 \\
\hline
\end{tabular}

Fig. 3. Top 15 insurance markets by total premium volume 
The increase in life premiums in emerging markets returned in 2019, after falling in 2018, the recovery was mainly driven by China. In emerging Asia, the volume of life premiums continued to grow supported by robust growth in key markets. In Latin America, the growth of premiums has expanded sharply, based on a strong increase in the return of demand for savings products in Brazil following social security reforms. Growth in the Middle East and Africa remained weak, reflecting the challenge of the region's economic environment.

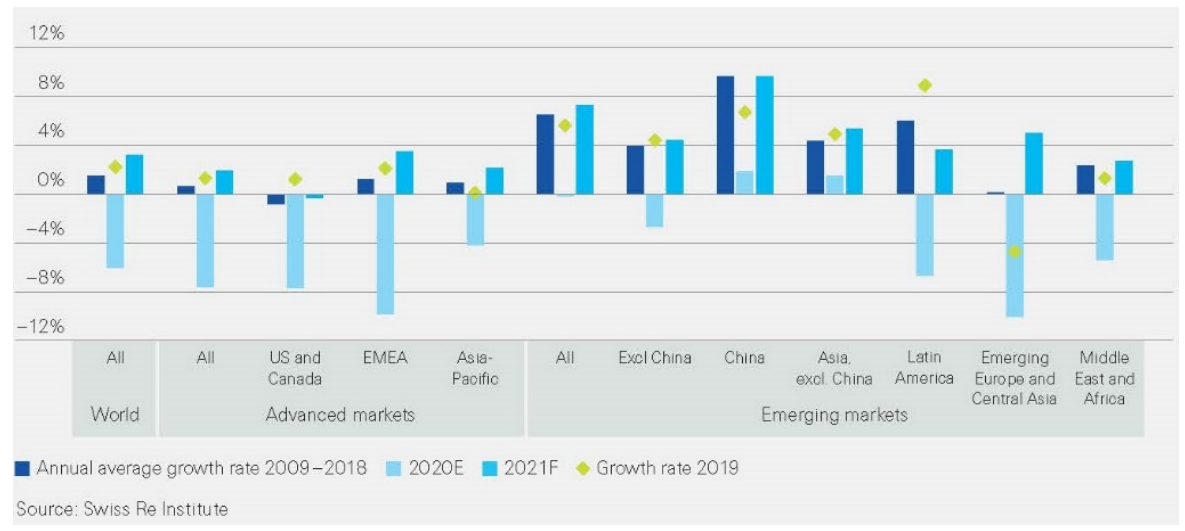

Fig. 4. Life real premium growth by region

The pandemic significantly changed the claims experiences for several types of insurance. In some countries there has been an increase in claims on the life insurance segment due to COVID-19.

The Covid-19 crisis has affected the solvency, profitability and profitability of the insurance sector, (fig. 5). Following an initial shock on the financial market, the insurance sector demonstrated resilience - helped, in some regions, by monetary and fiscal support measures on financial markets. However, potential vulnerabilities remain, given uncertainties about the duration of this crisis.

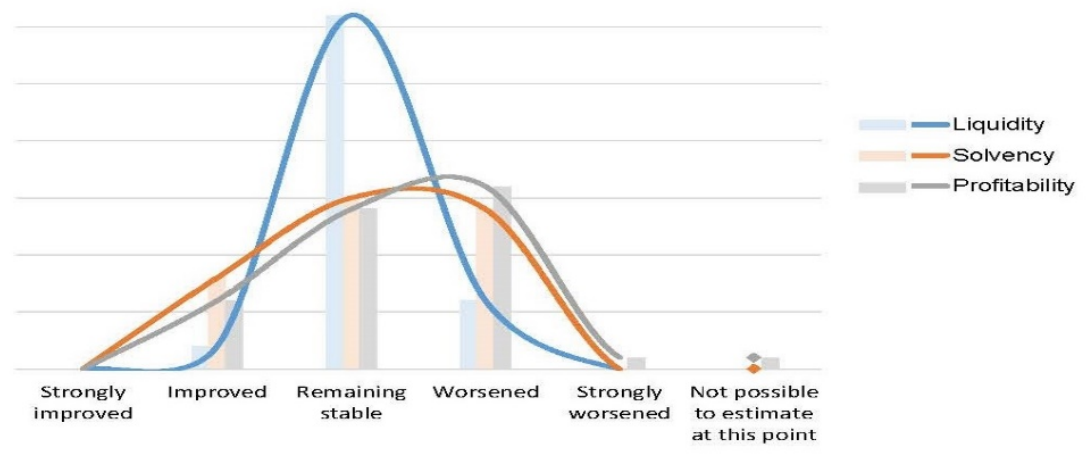

Source: IAIS SWM 2020 Q2 data

Fig. 5. Qualitative supervisory assessment of the impact of Covid-19

Based on data collected in the first half of 2020, the solvency rates of insurers have decreased slightly (fig. 6), but in general the sector capitalization remained resilient. Solvency rates have fallen in the first quarter of 2020, recovering somewhat in the second quarter. 


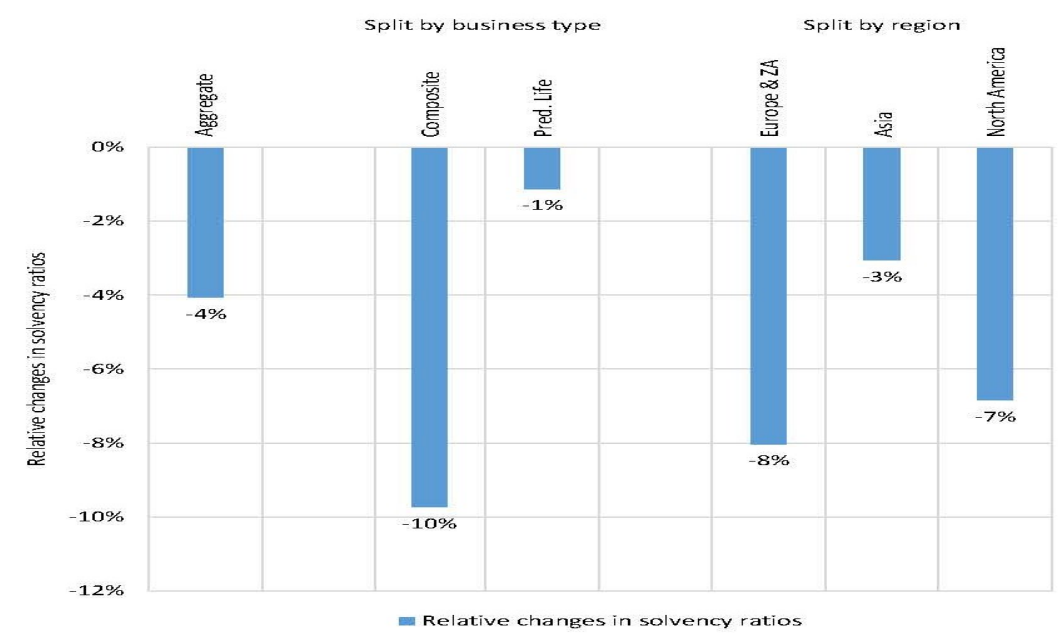

Source: IAIS IIM 2019 Q4, 2020 Q2 data

Fig. 6. Relative change in solvency ratios

Covid-19 has exerted significant pressure on profitability, by declining investment income, mainly for life and compound insurers. In the first half of 2020, the pandemic significantly affected investment income and, to a lesser extent, insurance business income. Investment income was mainly affected by depreciation and loss of investment in financial market recessions. The increased expenses associated with facilitating distance work and ensuring business continuity also put pressure on profitability for some insurers.

The impact on liquidity has been limited, without raising any immediate concerns about the ability of the insurance sector to meet its obligations in the first half of 2020. However, the pandemic has increased the overall liquidity and financing risk of the insurance sector and highlighted the importance of managing this risk.

The modification of asset portfolios of insurers was determined by the decrease in value and / or holdings from the equity portfolio, an increase in cash holdings and a strong increase in "other assets" category for certain insurers (fig. 7)

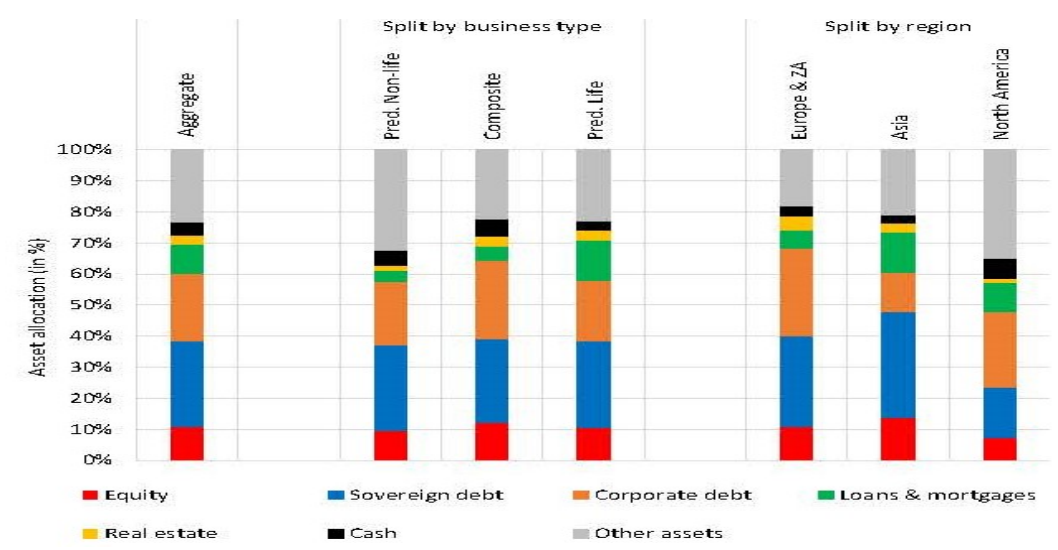

Source: IAIS IIM 2019 Q4, 2020 Q2 data

Fig. 7. Asset allocation of insurers 


\section{Conclusions}

Looking to the future, beyond the medium-term impact of the COVID-19 crisis, we also see more sustainable paradigm shifts affecting the insurance sector. In addition to weak monetary policy, with predominantly low interest rates for a longer period of time and a potential threat to inflation, it see three likely main developments:

- Raising risk awareness: Pandemics will not be fully insurable, but the COVID-19 crisis will raise awareness of the associated financial risks and trigger innovation for new types of insurance.

- Accelerated digital transformation: the blockages and implementation of social distancing rules have highlighted the importance and value of digitization through all stages of the insurance value chain. Distribution models need to be digitized to continue selling.

- The peak of globalization and parallel supply chains: the pandemic has highlighted the risk of undiversified supply chains.

Insurers should take additional steps to support their customers and the economy in general, through the following possible actions:

- premium / insurance contract flexibility (allowing delays in premium payments, switching between tariffs, cancelling and suspending policies)

- flexibility of the process and deadlines (maintaining customer insurance coverage with special attention to the practical consequences of the crisis)

- insurance contract goodwill actions (temporary extension of coverage and services beyond contractual obligations, offering free medical coverage to medical staff.

- support for the economy (investment models with a long-term perspective)

\section{References}

1. Bhuyan, V. - Life Markets, John Wiley \&Sons, Canada (2009)

2. Person, R - The development of international insurance, Pickering \& Chatto, London (2010)

3. Koklar, R. - Prediction of the insurance industry demand for a specific multinational company, European Scientific Journal, Volume 10, (2014)

4. *** IAIS-Gobal Insurance Market Report Covid-19 Edition (2020)

5. *** OECD-Global Insurance Market Trends 2020

6. *** Swiss Re Institute- Sigma no 4, World insurance:riding out the 2020 pandemic storm (2020)

7. $* * *$ Capgemini Research Institute -World Insurance Report (2020)

8. ***https://www.spglobal.com/ratings/en/sector/insurance/insurance-sector 